\title{
FAKTOR - FAKTOR YANG BERHUBUNGAN DENGAN KEJADIAN DIARE PADA BALITA DI PUSKESMAS SUNGAI RAYA KABUPATEN KUBU RAYA TAHUN 2019
}

\section{Megalina limoy ${ }^{1}$, Katarina Iit $^{2}$}

\author{
Akademi Kebidanan Panca Bhakti Pontianak \\ Email Korespondensi: limoy.elena@gmail.com
}

\begin{abstract}
Abstrak
Penyakit diare di Kota Pontianak merupakan masalah dari tahun ketahun, penyakit ini selalu ada dan dapat menimbulkan kejadian luar biasa (KLB) dan menyebabkan kematian terutama pada Balita. Angka kesakitan diare masih mengalami fluktuasi, mengingat banyaknya faktor yang mempengaruhi dan masih memerlukan waktu untuk peningkatannya seperti sanitasi lingkungan, faktor gizi, pendidikan, sosial ekonomi, kependudukan dan prilaku masyarakat baik langsung maupun tidak langsung. Tujuan dari penelitian ini adalah untuk mengetahui faktor-faktor yang mempengaruhi kejadian diare pada balita di Puskesmas sungai raya kecamatan suai raya kabupaten kubu raya. Jenis penelitian ini menggunakan pendekatan deskriptif korelasi dengan metode cross sectional untuk mengidentifikasi hubungan antara faktor-faktor yang mempengaruhi kejadian diare pada balita. Pengumpulan data dilakukan dengan cara menyebarkan kuesioner kepada responden. Ukuran sampel yang digunakan sebanyak 137 responden. Dari hasil penelitian ini didapatkan bahwa yang mempunyai hubungan yang signifikan dari faktor-faktor yang berhubungan dengan kejadian diare adalah status pekerjaan ibu OR=5,54 $(1,21-25,32)$ dan pengetahuan ibu OR=3,60 $(1,19-10,87)$. Sedangkan faktor-faktor yang tidak mempunyai hubungan yang signifikan antara lain umur ibu, pendidikan ibu, umur balita, status ASI, status gizi balita, sarana air bersih dan jamban.
\end{abstract}

Kata kunci: kejadian diare, balita, faktor-faktor, puskesmas

\section{Pendahuluan}

Penyakit diare masih merupakan masalah kesehatan masyarakat di Indonesia, saat ini angka kesakitan diare cenderung mengalami peningkatan dari tahun ke tahun dan sering menimbulkan Kejadian Luar Biasa (KLB) yang cukup banyak menyebabkan kematian (Depkes RI, Ditjen PP \& PL.,2017). Berdasarkan kajian dan analisis survei yang dilaksanakan oleh Didit P Diare 2018, gambaran angka morbiditas diare di Indonesia yang diukur dengan angka insiden per 1000 penduduk yaitu sebesar 280 pada tahun 1996, 301 pada tahun 2000, 347 pada tahun 2003 dan 423 pada tahun 2017.

Penyakit diare di Kota Pontianak merupakan masalah dari tahun ketahun,

\footnotetext{
${ }^{1}$ Dosen Akademi Kebidanan Panca Bhakti Pontianak

${ }^{2}$ Dosen Akademi Kebidanan Panca Bhakti Pontianak
}

penyakit ini selalu ada dan dapat menimbulkan kejadian luar biasa (KLB) dan menyebabkan kematian terutama pada Balita. Angka kesakitan diare masih mengalami fluktuasi, mengingat banyaknya faktor yang mempengaruhi dan masih memerlukan waktu untuk peningkatannya seperti sanitasi lingkungan, faktor gizi, pendidikan, sosial ekonomi, kependudukan dan prilaku masyarakat baik langsung maupun tidak langsung.

Di Wilayah Puskesmas sungai raya kecamatan suai raya kabupaten kubu raya sendiri jumlah penderita diare pada tahun 2017 sebanyak 3965 kasus, dimana Puskesmas yang berada di wilayah tersebut 
adalah rumah sakit Dr.M Soetomo Lanut Supadio. Jumlah kasus diare hampir merata di setiap puskesmas, akan tetapi di Puskesmas sungai raya belum pernah dilakukan penelitian mengenai faktor yag mempengaruhi kejadian diare.

\section{Metode}

Jenis penelitian yang digunakan dalam penelitian ini adalah deskriptif korelasi, yaitu penelitian yang diarahkan untuk mendeskripsikan atau menguraikan suatu keadaan di dalam suatu komunitas atau masyarakat (Notoatmodjo, 2007), dan untuk mengidentifikasi hubungan antara faktor- faktor yang mempengaruhi kejadian diare pada balita. Lokasi penelitian akan dilaksanakan di Puskesmas sungai raya kecamatan suai raya bulan Mei sampai dengan Agustus 2019. Populasi pada penelitian ini adalah seluruh ibu balita dan balita yang menderita diare yang datang berobat ke Puskesmas sungai raya kecamatan sungai raya sebesar 205 orang. Sampel dalam penelitian ini adalah 137 orang dan tingkat kebenaran dari penelitian ini adalah $95 \%$, maka sampelnya adalahUntuk menghindari DropOut, peneliti menambahkan 10\% dari total ukuran sample diatas, sehingga sample yang diperoleh adalah 150 orang.

\section{Hasil dan Pembahasan}

Tabel 1. Hasil Analisa

\begin{tabular}{|c|c|c|c|c|c|c|}
\hline \multirow{3}{*}{ Karakteristik } & \multicolumn{4}{|c|}{ Kejadian Diare } & \multirow{3}{*}{ P Value } & \multirow{3}{*}{ OR 95\% CI } \\
\hline & \multicolumn{2}{|c|}{$\begin{array}{l}\text { Penderita } \\
\text { Diare }\end{array}$} & \multicolumn{2}{|c|}{$\begin{array}{l}\text { Bukan } \\
\text { Penderita } \\
\text { Diare }\end{array}$} & & \\
\hline & $\mathrm{N}$ & $\%$ & $\mathrm{~N}$ & $\%$ & & \\
\hline \multicolumn{7}{|l|}{ Umur Ibu } \\
\hline$\leq 25$ Tahun & 65 & 92,9 & 5 & 7,1 & \multirow{2}{*}{0,99} & 2,83 \\
\hline$>25$ Tahun & 55 & 82,1 & 12 & 17,9 & & $(0,94-8,54)$ \\
\hline \multicolumn{7}{|l|}{ Pendidikan } \\
\hline Rendah & 54 & 93,1 & 4 & 6,9 & \multirow{3}{*}{0,15} & 2,65 \\
\hline Tinggi & 66 & 83,5 & 13 & 16,5 & & $(0,82-8,62)$ \\
\hline \multicolumn{6}{|l|}{ Status Pekerjaan Ibu } & \\
\hline Kerja & 51 & 96,2 & 2 & 3,8 & \multirow{3}{*}{0,03} & 5,54 \\
\hline Tidak Bekerja & 69 & 82,1 & 15 & 17,9 & & $(1,21-25,32)$ \\
\hline \multicolumn{6}{|l|}{ Pengetahuan } & \\
\hline Rendah & 72 & 93,5 & 5 & 6,5 & \multirow{3}{*}{0,03} & 3,60 \\
\hline Tinggi & 48 & 80 & 12 & 20 & & $(1,19-10,87)$ \\
\hline \multicolumn{6}{|l|}{ Umur Balita } & \\
\hline 12-59 Bulan & 73 & 90,1 & 8 & 9,9 & \multirow{3}{*}{0,41} & 1,74 \\
\hline 0-11 Bulan & 47 & 83,9 & 9 & 16,1 & & $(0,63-4,84)$ \\
\hline \multicolumn{6}{|l|}{ Status Asi } & \\
\hline Eksklusif & 69 & 92,0 & 6 & 8,0 & \multirow{2}{*}{0,14} & \multirow{2}{*}{$\begin{array}{c}2,48 \\
(0,86-7,14)\end{array}$} \\
\hline $\begin{array}{l}\text { Tidak Eksklusif } \\
\text { Status Gizi }\end{array}$ & 51 & 82,3 & 11 & 17,7 & & \\
\hline Gizi Kurang & 15 & 93,8 & 1 & 6,3 & \multirow{2}{*}{0,69} & \multirow{2}{*}{$\begin{array}{c}2,28 \\
(0,28-18,50\end{array}$} \\
\hline Gizi Baik & 105 & 86,8 & 16 & 13,2 & & \\
\hline
\end{tabular}




\begin{tabular}{lcccccc}
\hline Tidak Memenuhi Syarat & 38 & 86,4 & 6 & 13,6 & 0,98 & 0,85 \\
Memenuhi Syarat & 82 & 88,2 & 11 & 11,8 & & $(0,29-2,46)$ \\
$\begin{array}{l}\text { Jamban } \\
\text { Tidak Memenuhi Syarat }\end{array}$ & 36 & 90 & 4 & 10 & & 1,39 \\
Memenuhi Syarat & 84 & 86,6 & 13 & 13,4 & 0,79 & $(0,42-4,56)$ \\
\hline
\end{tabular}

Hasil analisis hubungan antara umur ibu dengan kejadian diare pada balita diperoleh bahwa ada sebanyak 65 dari 70 (92,9\%) umur ibu kurang dari 25 tahun memiliki balita yang menderita diare. Sedangkan diantara ibu yang berumur lebih dari 26 tahun, ada 55 dari $67(82,1 \%)$ memiliki balita yang menderita diare. Hasil uji statistik diperoleh nilai $\mathrm{p}=0,99$ maka dapat disimpulkan tidak ada perbedaan proporsi kejadian diare antara ibu yang berumur kurang dari 25 tahun dengan ibu yang berumur lebih dari 26 tahun (tidak ada hubungan yang signifikan antara umur ibu dengan kejadian diare pada balita). Dari hasil analisis diperoleh nilai $\mathrm{OR}=2,83(0,94-8,54)$, artinya ibu yang berumur kurang dari 25 tahun mempunyai peluang 2,8 kali memiliki balita yang menderita diare dibandingkan ibu yang berumur lebih dari 26 tahun.

Umur ibu tidak berhubungan secara bermakna dengan kejadian diare dengan $\mathrm{OR}=$ $2,83(0,94-8,54)$. Umur ibu merupakan faktor predisposisi terjadinya perubahan perilaku yang berkaitan dengan kematangan fisik dan psikis ibu balita. Hal ini sesuai dengan hasil penelitian Betrand dan Walnus di Columbia (1983) dalam Giyantini (2000) yang menyatakan bahwa umur berhubungan dengan diare. Dimana kelompok umur 20 sampai dengan 40 tahun akan melindungi terjadinya diare kemungkinan disebabkan oleh kelompok umur tersebut telah berpengalaman dalam merawat balita.

Hasil analisis hubungan antara pendidikan ibu dengan kejadian diare pada balita diperoleh bahwa ada sebanyak 54 dari $58(93,1 \%)$ pendidikan ibu yang rendah memiliki balita yang menderita diare. Sedangkan diantara ibu yang memiliki pendidikan tinggi, ada 66 dari $79(83,5 \%)$ memiliki balita yang menderita diare. Hasil uji statistik diperoleh nilai $\mathrm{p}=0,15$ maka dapat disimpulkan tidak ada perbedaan proporsi kejadian diare antara pendidikan ibu yang rendah dengan ibu yang memiliki pendidikan tinggi (tidak ada hubungan yang signifikan antara pendidikan ibu dengan kejadian diare pada balita). Dari hasil analisis diperoleh nilai $\mathrm{OR}=2,65(0,82-8,62)$, artinya ibu yang memiliki pendidikan rendah mempunyai peluang 2,65 kali memiliki balita yang menderita diare dibandingkan ibumemiliki pendidikan tinggi.

Pendidikan ibu sangat erat kaitannya dengan kesehatan keluarga. Ibu umumnya sangat berperan dalam pemeliharaan kesehatan balita.Tingkat pendidikan rendah menyebabkan kesulitan menyerap informasi atau gagasan baru, sebaliknya seseorang yang memiliki tingkat pendidikan tinggi akan lebih terbuka menerma gagasan baru (Kusnodiharjo, dkk, 1994). Upaya peningkatan pendidikan membutuhkan dana 
yang cukup dan waktu yang lama untuk menanggulangi keadaan di masyarakat, perlu mengetahui pencegahan diare sehingga diperlukan penyuluhan secara langsung di posyandu, puskesmas, dan sarana kesehatan lainnya. Dan penyuluhan secara tidak langsung melalui media cetak atau elektronik diharapkan masyarakat mempunyai perilaku positif terhadap perilaku hidup bersih dan sehat.

Hasil analisis hubungan antara status pekerjaan ibu dengan kejadian diare pada balita diperoleh bahwa ada sebanyak 51 dari $53(96,3 \%)$ ibu yang ibu yang bekerja memiliki balita yang menderita diare. Sedangkan diantara ibu yang tidak bekerja, ada 69 dari $84(82,1 \%)$ memiliki balita yang menderita diare. Hasil uji statistik diperoleh nilai $\mathrm{p}=0,03$ maka dapat disimpulkan ada perbedaan proporsi kejadian diare antara ibu yang bekerja dengan ibu yang tidak bekerja (ada hubungan yang signifikan antara status pekerjaan ibu dengan kejadian diare pada balita). Dari hasil analisis diperoleh nilai $\mathrm{OR}=$ 5,54 (1,21 - 25,32), artinya ibu yang bekerja mempunyai peluang 5,5 kali memiliki balita yang menderita diare dibandingkan ibu yang tidak bekerja.

Pekerjaan ibu dengan pengertian bekerja atau tidak bekerja merupakan hal yang penting dalam pemberian perhatian dan peralatan yang cukup bagi balita agar tidak terjadi diare. Menurut Joko Irianto, dkk tahun 1996 melaporkan bahwa pekerjaan ibu maupun keaktifan ibu dalam organisasi sosial mempunyai hubungan yang bermakna dengan kejadian diare pada anak balita.

Hasil analisis hubungan antara pengetahuan ibu dengan kejadian diare pada balita diperoleh bahwa ada sebanyak 72 dari $77(93,5 \%)$ pengetahuan ibu yang rendah tentang diare memiliki balita yang menderita diare. Sedangkan diantara ibu yang memiliki pengetahuan tinggi, ada 48 dari 60 (80\%) memiliki balita yang menderita diare. Hasil uji statistik diperoleh nilai $\mathrm{p}=0,03$ maka dapat disimpulkan ada perbedaan proporsi kejadian diare antara pengetahuan ibu yang rendah tentang diare dengan ibu yang memiliki pengetahuan tinggi (ada hubungan yang signifikan antara pengetahuan ibu dengan kejadian diare pada balita). Dari hasil analisis diperoleh nilai $\mathrm{OR}=3,60(1,19-10,87)$, artinya ibu yang memiliki pengetahuan rendah mempunyai peluang 3,6 kali memiliki balita yang menderita diare dibandingkan ibu memiliki pengetahuan tinggi.

Pada aspek pengetahuan ibu, rendahnya pengetahuan ibu mengenai hidup sehat merupakan faktor risiko yang menyebabkan penyakit diare pada bayi dan balita. Upaya yang harus dilakukan untuk meningkatkan pengetahuan ibu dalam mencegah dan menanggulangi diare pada balita adalah memberi informasi yang tepat, berkelanjutan dan terus-menerus melalui penyuluhan langsung atau melalui media. Penyuluhan di posyandu akan memberikan hasil yang baik bila petugas mau dan terampil dalam memberikan penyuluhan. Oleh karena itu, sebaiknya petugas posyandu diberi pelatihan 
tentang cara-cara penyuluhan disamping bimbingan teknis dari petugas kesehatan. Materi yang disampikan sebaiknya dikemas sedemikian rupa sehingga pesan yang disampaikan mudah dimengerti dan disukai masyarakat.

Hasil analisis hubungan antara umur balita dengan kejadian diare pada balita diperoleh bahwa ada sebanyak 73 dari 81 $(90,1 \%)$ umur balita $12-59$ bulan menderita diare. Sedangkan diantara balita yang berumur 0-11 bulan, ada 47 dari $56(83,9 \%)$ balita yang menderita diare. Hasil uji statistik diperoleh nilai $\mathrm{p}=0,41$, maka dapat disimpulkan tidak ada perbedaan proporsi kejadian diare antara balita yang berumur 12-59 bulan dengan balita yang berumur 0-11 bulan ( tidak ada hubungan yang signifikan antara umur balita dengan kejadian diare pada balita). Dari hasil analisis diperoleh nilai $\mathrm{OR}=1,74(0,63-4,84)$, artinya balita yang berumur 12-59 bulan mempunyai peluang 1,7 kali menderita diare dibandingkan balita yang berumur 0-11 bulan.

Di Indonesia, dilaporkan bahwa tiap anak mengalami diare sebanyak 1-2 episode per tahun (Depkes, 2003). Berdasarkan umur, prevalensi tertinggi terjadi pada usia 6-11 bulan $(19,4 \%), 12-23$ bulan $(14,8 \%)$, dan $24-$ 35 bulan (12,0\%) (Biro Pusat Statistik, 2003).Umur khususnya pada anak-anak berkaitan erat dengan tingkat ketahanan anak terhadap serangan penyakit. Umumnya bayi masih mempunyai tingkat ketahanan bawaan dari ibunya, namun makin beranjak besar, anak mulai berjalan dan banyak beraktifitas sehingga kebersihan menjadi sangat penting.
Keadaan gizi juga berkaitan terhadap daya tahan tubuh anak terhadap serangan penyakit.

Hasil analisis hubungan antara status ASI dengan kejadian diare pada balita diperoleh bahwa ada sebanyak 69 dari 75 $(92,0 \%)$ balita yang tidak mendapatkan ASI eksklusif menderita diare. Sedangkan diantara balita yang mendapatkan ASI eksklusif, ada 51 dari $62(82,3 \%)$ balita yang menderita diare. Hasil uji statistik diperoleh nilai $\mathrm{p}=$ 0,14, maka dapat disimpulkan tidak ada perbedaan proporsi kejadian diare antara balita yang tidak mendapatkan ASI eksklusif dengan balita yang mendapatkan ASI eksklusif (tidak ada hubungan yang signifikan antara status ASI dengan kejadian diare pada balita).

Dari hasil analisis diperoleh nilai $\mathrm{OR}=$ 2,48 (0,86- 7,14), artinya balita yang tidak mendapatkan ASI eksklusif mempunyai peluang 2,48 kali menderita diare dibandingkan balita yang mendapatkan ASI eksklusif. ASI saja sudah cukup untuk menjaga pertumbuhan sampai umur 4-6 bulan dan tidak ada makanan lain yang dibutuhkan selama masa ini.ASI bersifat steril, berbeda dengan sumber susu lain seperti susu formula atau cairan lain yang disiapkan dengan air atau bahan-bahan dapat terkontaminasi dalam botol yang kotor.Penggunaan botol susu formula, beresiko tinggi menyebabkan diare yang dapat mengakibatkan terjadinya gizi buruk.Pemberian ASI saja tanpa cairan atau makanan lain dan tanpa menggunakan botol, menghindarkan anak dari bahaya bakteri dan organisme lain yang akan menyebabkan diare. 
Hasil analisis hubungan antara status gizi dengan kejadian diare pada balita diperoleh bahwa ada sebanyak 15 dari 16 $(93,8 \%)$ balita yang mengalami gizi kurang menderita diare. Sedangkan diantara balita yang mengalami gizi baik, ada 105 dari 121 $(86,8 \%)$ balita yang menderita diare. Hasil uji statistik diperoleh nilai $\mathrm{p}=0,69$, maka dapat disimpulkan tidak ada perbedaan proporsi kejadian diare antara balita yang mengalami gizi kurang dengan balita yang mengalami gizi baik (tidak ada hubungan yang signifikan antara status gizi dengan kejadian diare pada balita). Dari hasil analisis diperoleh nilai $\mathrm{OR}=$ $2,28(0,28-18,50)$, artinya balita yang mengalami gizi kurang mempunyai peluang 2,28 kali menderita diare dibandingkan balita yang mengalami gizi baik.

Dari beberapa aspek yang diteliti status gizi memiliki faktor risiko yang signifikan dalam menyebabkan penyakit diare padabayi dan balita, rendahnya status gizi pada bayi dan balita merupakan faktor risiko yang rentan untuk menyebabkan penyakit diare (Wiku Adisasmito, 2007). Diare menyebabkan kegagalan pertumbuhan bahkan kehilangan berat badan yang menetap, melampaui kehilangan berat badan yang disebabkan oleh kehilangan cairan atau dehidrasi. Hal ini berakibat pada penurunan daya tahan tubuh atau kekebalan tubuh balita sehingga berdampak buruk terhadap anak yang menderita diare berulang-ulang. Anak yang sering menderita diare atau menderita diare persisten akan lebih sering menderita gizi kurang dari pada anak yang jarang menderita diare.

Hasil analisis hubungan antara sarana air bersih dengan kejadian diare pada balita diperoleh bahwa ada sebanyak 38 dari 44 $(86,4 \%)$ balita yang memiliki sarana air bersih tidak memenuhi syarat menderita diare. Sedangkan diantara balita yang memiliki sarana air bersih yang memenuhi syarat, ada 82 dari $93(88,2 \%)$ balita yang menderita diare. Hasil uji statistik diperoleh nilai $\mathrm{p}=$ 0,98, maka dapat disimpulkan tidak ada perbedaan proporsi kejadian diare antara balita yang memiliki sarana air bersih tidak memenuhi syarat dengan balita yang memiliki sarana air bersih memenuhi syarat (tidak ada hubungan yang signifikan antara sarana air bersih dengan kejadian diare pada balita). Dari hasil analisis diperoleh nilai $\mathrm{OR}=0,85(0,29$ 2,46 ), artinya balita yang sarana air bersih tidak memenuhi syarat mempunyai peluang 0,85 kali menderita diare dibandingkan balita yang memiliki sarana air bersih memenuhi syarat. Dengan pembangunan sarana yang tidak memenuhi syarat, air yang dihasilkan akan memenuhi kualitas dan tidak tercemar. Pemerintah kota kabupaten kubu raya membangun partisipasi masyarakat untuk membangun sarana dan mengelolanya dengan baik sehingga kebutuhan dasar masyarakat akan air bersih tercukupi dan pencegahan penyakit diare dapat terwujud.

Hasil analisis hubungan antara jamban dengan kejadian diare pada balita diperoleh bahwa ada sebanyak 36 dari $40(90,0 \%)$ balita yang memiliki jamban yang tidak memenuhi 
syarat menderita diare. Sedangkan diantara balita jambannya memenuhi syarat, ada 84 dari 97 (86,6\%) balita yang menderita diare. Hasil uji statistik diperoleh nilai $\mathrm{p}=0,79$, maka dapat disimpulkan tidak ada perbedaan proporsi kejadian diare antara balita yang jambannya tidak memenuhi syarat dengan yang memenuhi syarat (tidak ada hubungan yang signifikan antara jamban dengan kejadian diare pada balita). Dari hasil analisis diperoleh nilai $\mathrm{OR}=1,393(0,42-4,56)$, artinya

\section{Kesimpulan}

1. Umur ibu tidak berhubungan secara bermakna dengan kejadian diare dengan $\mathrm{OR}=2,836 \quad(0,941-8,549)$. Umur ibu merupakan faktor predisposisi terjadinya perubahan perilaku yang berkaitan dengan kematangan fisik dan psikis ibu balita.

2. Pendidikan ibu tidak berhubungan secara bermakna dengan kejadian diare dengan $\mathrm{OR}=2,65(0,820-8,627)$. Pendidikan ibu sangat erat kaitannya dengan kesehatan balita.

3. Ibu bekerja berhubungan secara bermakna dengan kejadian diare dengan $\mathrm{OR}=5,543$ $(1,213$ - 25,32). Pekerjaan ibu dengan pengertian bekerja atau tidak bekerja merupakan hal yang penting dalam pemberian perhatian dan peralatan yang ckup bagi balita agar tiak terjadi diare.

4. Pengetahuan ibu berhubungan secara bermakna dengan kejadian diare dengan $\mathrm{OR}=3,60(1,192-10,873)$. Pengetahuan atau kognitif merupakan dominan yang balita yang jambannya tidak memenuhi syarat mempunyai peluang 1,39 kali menderita diare dibandingkan balita yang jambannya memenuhi syarat. Berdasarkan Survei Demografi dan Kesehatan di Indonesia tahun 1994, risiko untuk diare pada kelompok yang tidak menggunakan jamban keluarga 1,7 kali lebih besar di bandingkan dengan kelompok yang menggunakan jamban. Oleh karena itulah setiap rumah tangga harus dipersyaratkan memiliki jamban keluarga.

sangat penting dalam membentuk tindakan seseorang.

5. Umur balita tidak berhubungan secara bermakna dengan kejadian diare dengan $\mathrm{OR}=1,747(0,630-4,848)$. Umur anak berkaitan dengan tingkat ketahanan anak terhadap serangan penyakit.

6. Status ASI tidak berhubungan secara bermakna dengan kejadian diare dengan $\mathrm{OR}=2,48(0,861-7,149)$. Air Susu Ibu (ASI) merupakan makanan terbaik bagi bayi, karena mempunyai manfaat pencegahan penyakit karena adanya antibody.

7. Status gizi balita tidak berhubungan secara bermakna dengan kejadian diare dengan $\mathrm{OR}=2,286(0,282-18,501)$. Keadaan gizi berkaitan terhadap daya tahan tubuh anak terhadap serangan penyakit.

8. Sarana air bersih (SAB) tidak berhubungan secara bermakna dengan kejadian diare dengan $\mathrm{OR}=0,850(0,292$ 2,468). Faktor risiko penyebab penyakit 
diare adalah faktor lingkungan yang berkaitan dengan sanitasi sarana air bersih

9. Kepemilikan jamban tidak berhubungan secara bermakna dengan kejadian diare dengan $\mathrm{OR}=1,393(0,425-4,563)$. Kondisi jamban merupakan salah satu faktor yang dapat meningkatkan risiko terhadap terjadinya diare.

Berdasarkan hasil penelitian bahwa faktor pengetahuan ibu dan pemberian ASI eksklusif

\section{Daftar Pustaka}

Adisamito, Wiku. 2007. Faktor-faktor yang berhubungan dengan kejadian diare di Aceh Utara. Depok. UI

Budi, Setia. 2006. Diare Akut Pada Anak. Journal Medica Nusantara vol.27 no.2 April- Juni. Jakarta

Chin, James, Editor Penterjemah: dr. I Nyoman Kandun, 2000. Manual Pemberantasan Penyakit Menular, Ditjen PP \& PL, Depkes, Jakarta

Dahlan, Sopiyudin, 2006.Besar Sampel Dalam Penelitian Kedokteran dan Kesehatan. ARKANS, Jakarta.

Departemen Kesehatan RI, 2007. Pedoman Pemberantasan Penyakit Diare, Edisi ke 5, Ditjen PPM dan PL, Jakarta.

\begin{tabular}{lll} 
& $2006 \&$ 2007. & Profil \\
\hline Kesehatan Kota Bekasi, & Dinas \\
Kesehatan Kota Bekasi, Bekasi. &
\end{tabular}
1981. Diare dan Upaya Pemberantasan, Dit.Jen PPM \& PL, Depkes RI, Jakarta

2000. Profil Kesehatan Indonesi 2000, Pusat Data Kesehatan Indonesia, Depkes RI, Jakarta.

Kesehatan berhubungan dengan kejadian diare, diharapkan Puskesmas dapat merencanakan tindakan pencegahan dan penanggulangan terhadap kejadian penyakit diare yang dapat menimbulkan KLB dengan menggiatkan penyuluhan terhadap masyarakat mengenai pemberian ASI eksklusif, perilaku hidup bersih dan sehat.

No.1116/Menkes/SK/VIII/2003,

Pedoman Penyelenggaraan Sistem Surveilens Epidemiologi Kesehatan, Ditjen PPM \& PL, Jakarta.

,1998. Inspeksi Sanitasi Sarana Air Bersih, Dit.Jen PPM \& PL, Departemen Kesehatan R.I., Jakarta.

Kusnoputranto, H, 1997. Air Limbah dan Eksreta Manusia, Dirjen Pendidikan Tinggi Depdikbud, Jakarta

Murti, Bhisma, 2006.Desain dan Ukuran Sampel Untuk Penelitian Kuantitatif dan Kualitatif di Bidang Kesehatan, Gajah Mada University Press, Yogyakarta.

Notoatmodjo Soekijo dkk, 1990. Promosi Kesehatan dan Ilmu Perilaku, Rineka Cipta.

2002. Metodologi Penelitian Kesehatan. Rineka Cipta, Jakarta

Purwanto, Hari, 1997. Hubungan Faktor Sosial Ekonomi Keluarga dan Faktor Lingkungan Dengan Kejadian Diare Pada Balita Di Indonesia (Analisis Data Survei Demografi dan Kesehatan 1994), Tesis, Program Pascasarjana, Program Studi Ilmu Kesehatan Masyarakat, UI, Jakarta

Ridwan. 2005. Belajar Mudah Penelitian Untuk Guru - Karyawan - Dan Peneliti Pemula, Alfhabeta. 2005 , Bandung. 
Sudjana. 1996. Metode Statistika edisi ke 6. Tarsito, Bandung.

Sugiyono. 2004. Metode Penelitian Administrasi, Edisi 10. Alfhabeta, Bandung.

Yati Hayati, Ace, 1992. Hubungan Air Bersih dan Jamban Dengan Kesakitan Diare Pada Balita di Kabupaten Belu NTT, Tesis, Program Pascasarjana, Program Studi Ilmu Kesehatan Masyarakat, UI, Jakarta 